\title{
Antibacterial activity and in situ efficacy of Bidens pilosa Linn and Dichrostachys cinerea Wight et Arn extracts against common diarrhoea-causing waterborne bacteria
}

Pfarelo Daphney Shandukani, Shonisani Cathphonia Tshidino, Peter Masoko and Kgabo Maureen Moganedi* (D)

\begin{abstract}
Background: Bidens pilosa and Dichrostachys cinerea extracts were investigated for the antibacterial properties against waterborne diarrhoeagenic bacteria.

Methods: The plant materials were extracted using the direct and serial exhaustive methods using solvents of varying polarities, namely, hexane, dichloromethane, ethyl acetate, acetone and methanol. Qualitative phytochemical analysis and quantitative determination of total phenolic content of the leaf powders of the two plants were tested. The antioxidant activities of the plants were determined using the 2, 2-diphenyl-1-picrylhydrazyl method. The toxic effect of the extracts on C2C12 muscle cell line were assessed by the 3-(4,5-dimethylthiazol-2-yl)-2, 5-diphenyltetrazolium bromide method and the antibacterial activity was determined using the serial microbroth dilution.

Results: Methanol leaf extracts both plants had the highest yield in both direct and serial exhaustive extraction methods. Phytochemical profiling of the extracts displayed the presence of various secondary metabolites. The Benzene: ethanol: ammonia hydroxide solvent system showed a good resolution of chemical compounds in plant extracts from both plants. Most antioxidant compounds observed were developed in chloroform: ethyl acetate: formic acid and ethyl acetate: methanol: water solvent systems. All the bacterial species tested were sensitive to the effect of different extracts of both plant species, with $E$. coli being less sensitive to the effect of the extracts from $D$. cinerea. Following the simulated gastric fluid (SGF) treatment, a decrease in the antibacterial potency of the extracts was observed. No extract was toxic to the C2C12 muscle cell line.

Conclusion: The presence of the secondary metabolites and nontoxic effect of the two plants tested may affirm the medicinal value of these leaf extracts. Our results suggest that B. pilosa and D. cinerea contain constituents with antioxidant and antimicrobial activities, which could be used in the treatment of diarrhoea in a case where untreated surface water is used.
\end{abstract}

Keywords: Diarrhoea, Simulated gastric fluid, Medicinal plants, Antibacterial activity, Probiotics

\footnotetext{
* Correspondence: kgabo.moganedi@ul.ac.za

Department of Biochemistry, Microbiology and Biotechnology, University of Limpopo, Private Bag X1106, Sovenga 0727, South Africa
}

(c) The Author(s). 2018 Open Access This article is distributed under the terms of the Creative Commons Attribution 4.0 International License (http://creativecommons.org/licenses/by/4.0/) which permits unrestricted use, distribution, and reproduction in any medium, provided you give appropriate credit to the original author(s) and the source, provide a link to the Creative Commons license, and indicate if changes were made. The Creative Commons Public Domain Dedication waiver (http://creativecommons.org/publicdomain/zero/1.0/) applies to the data made available in this article, unless otherwise stated. 


\section{Background}

Many communities in South Africa still depend on untreated surface water for their domestic needs such as drinking, cooking, laundry and for personal hygiene [1], due to the shortage of potable water. Surface water is not safe for human consumption and its consumption often results in waterborne diseases such as gastroenteritis, which can be very severe in immunocompromised individuals and children with underdeveloped immune systems [2]. Water-borne diarrhoea and increased bacterial drug-resistance remain a challenge for public health [3]. Diarrhoea constitutes a major cause of morbidity and mortality in South Africa [4], due to widespread usage of non-potable water sources and unhygienic practices. The importance of diarrhoea as a public health problem is marked by relatively reduced number of drugs for its treatment due to their high costs [5]. The high costs of antibiotics [6] and shortage of healthcare facilities in some regions of South Africa [7] leave many affected people with few options for the treatment of infections.

Medicinal plants are commonly used in Africa in the treatment of many ailments and constitute the first health recourse for about $80 \%$ of the population [8]. Many rural communities in South Africa still rely on traditional medicines for the treatment of gastric ailments and other diseases [9]. Medicinal plants are rich in compounds that may potentially be natural drugs, which may serve as sources of alternative, affordable and safe antimicrobial treatment for common diseases. Considering the levels of dependency on medicinal plant remedies, scientific research studies have largely reported on the antibacterial and other medicinal properties of the traditional medicinal plants. However, there is less consideration for the investigation of the safety and in situ efficacy of plant extracts used in the treatment of ailments such as diarrhoea. Properties such as potency, possible presence of toxic compounds, spectrum range of the antimicrobial agents and their effect on normal and beneficial flora should be considered with the use of plant preparations. These factors form an integral part in the evaluation process of drug leads. It is thus important to investigate the effectiveness of the plants used for the treatment of diarrhoea, and to further study secondary complications, which may result from the usage of medicinal plants used traditionally to treat diarrhoea based on indigenous knowledge.

Dichrostachys cinerea Wight et Arn. and Bidens pilosa Linn were investigated in this study due to their wide usage in the treatment of diarrhoea in rural communities. These plant species are used by the vhaVenda people for the treatment of diarrhoea as prescribed by the traditional healers and the herbalists [10], Ramathavha $\mathrm{R}$ and Nemakwelengwe $M$ (pers. com). The dried fruits of $D$. cinerea are commonly used as condiments $[11,12]$, for the management of fever and headache [13] and have been reported to have antioxidant activity [14-16] and anti-hypertensive and antibacterial effects $[17,18]$.

Bidens pilosa $L$. is a species of flowering plant of the Asteraceae family. In South Africa, B. pilosa is found mostly in the wild and homestead gardens in the KwaZulu-Natal and Limpopo Provinces [19]. It is commonly known as Black-jack in South Africa and other countries [20]. Although B. pilosa is considered a weed in some parts of the world, in Africa it is commonly consumed as a rich source of food and medicine for human and animals [21, 22]. The aerial parts of B. pilosa, i.e., the leaves, flowers, seeds, stems and roots are used in folk medicine as dry powder, decoction, maceration or tincture [23]. The B. pilosa extracts have been reported to possess antiviral [24], antifungal [25] and antibacterial properties [26-28].

The purpose of this study was to investigate the antibacterial properties of $D$. cinerea and B. pilosa extracts against a wide spectrum of common waterborne diarrhoea-causing bacteria. Notably, B. pilosa has not been tested specifically for anti-diarrhoeal efficacy, while $D$. cinerea has been reported [29]. Little information is available on the unintended effects that emanate from consumption of $D$. cinerea preparations. It is deemed appropriate that when testing for anti-diarrhoeal properties of medicinal plants, a wide spectrum of appropriate microbiota, which are associated with and are commonly implicated in diarrhoeal episodes in humans are used. It is important to broaden the knowledge on the effectiveness of these selected plants as sources of anti-diarrhoeal agents against common diarrhoea causing bacteria; to support their traditional use and to further shed light on the potential unintended effects associated with consumption of their herbal preparations. The unintended effects of the plant extracts include their effect on probiotics and their retention of antibacterial potency following exposure to gastric fluid.

\section{Methods \\ Plants collection}

The selection of medicinal plants was based on their traditional use as reported in Mabogo [10] and from personal communication with herbalists (Ramathavha $\mathrm{R}$ and Nemakwelengwe M, pers. com, 2014). Leaves of B. pilosa Linn (Voucher specimen no: UNIN 12895) and D. cinerea Chiov, (Voucher specimen no: UNIN 12894) were collected from Venda (Miluwani village) and Mankweng area (University of Limpopo) in the Limpopo Province. The Larry Leach Herbarium (UNIN) at the University of Limpopo was used as reference point for the identification of plants and as a repository for voucher specimens.

\section{Plant extraction}

Collected plant materials were air-dried in the dark at room temperature for several days, ground with an electric grinder into fine powders and stored in airtight 
containers. The powdered plant materials were subjected to extraction using the direct and serial exhaustive methods [30, 31]. Briefly, 2 and $5 \mathrm{~g}$ of powdered leaves were separately mixed with $20 \mathrm{~mL}$ and $50 \mathrm{~mL}$ of hexane, dichloromethane, ethyl acetate, acetone and methanol according to the solvents polarities from non-polar to the more polar solvent in polyester centrifuge tubes. The tubes were shaken for $30 \mathrm{~min}$ at room temperature in a series 2 incubator shaker (New Brunswick Scientific Co., Inc) at $200 \mathrm{rpm}$. The plant extract was filtered into pre-weighed labelled vial through a Whatman No. 1 filter paper. The process was repeated three times until the plant constituents were fully collected and the extracts were combined. The solvents were removed under a stream of cold air using a fan. Dried extracts were weighed, recorded and reconstituted in acetone to obtain stock solutions of $100 \mathrm{mg} / \mathrm{mL}$. Extracts were stored as aliquots at $-20{ }^{\circ} \mathrm{C}$ until further tests for phytochemicals and antibacterial activity.

\section{Determination of phytoconstituents}

Qualitative phytochemical analyses of B. pilosa and D. cinerea leaf powders were done for the following classes of secondary metabolites: total phenols [32], terpenoids, steroids and flavonoids [33] and saponins [34].

\section{Screening for phytochemical compounds}

The chemical constituents of the plant extracts were also analysed by thin layer chromatography (TLC) using aluminium-backed TLC plates (Silica gel F254, Fluka) as reported by Kotze and Eloff [30]. Ten microliter of each extract $(10 \mathrm{mg} / \mathrm{mL})$ was loaded on TLC plates and developed in saturated chambers using three mobile phases of different polarities; namely, benzene/ethyl acetate/ammonia hydroxide (BEA) (non-polar/basic) (9:1:0.1), chloroform/ethyl acetate/formic acid (CEF) (intermediate polarity/ acidic) (5:4:1) and ethyl acetate/methanol/water (EMW) (polar/neutral) (10:5.4:4). The TLC plates were dried in the fume-hood. The developed compounds on the TLC plates were examined under ultraviolet light (254 and $365 \mathrm{~nm}$ ) and sprayed with vanillin-sulphuric acid reagent $[0.1 \mathrm{~g}$ vanillin (Sigma ${ }^{\circ}$ ): $28 \mathrm{~mL}$ methanol: $1 \mathrm{~mL}$ concentrated sulphuric acid] and heated at $110{ }^{\circ} \mathrm{C}$ for optimal colour development.

\section{Qualitative antioxidant activity}

Antioxidant activity was determined using the 2, 2-diphenyl-1-picrylhydrazyl (DPPH) free radical scavenging ability as reported by Deby and Margotteaux [35]. Thin Layer Chromatography (TLC) plates were developed as described above. The plates were sprayed with $0.2 \%(w / v) \mathrm{DPPH}$ in methanol as an indicator. The presence of antioxidant compounds was detected by yellow spots against a purple background on the TLC plates.

\section{Quantitative determination of total phenolic content}

The amount of total phenolics in the extracts was quantitatively determined with the Folin-Ciocalteu method [36]. Plant extracts were dissolved in methanol to achieve a concentration of $2 \mathrm{mg} / \mathrm{mL}$. A blank was prepared from all the reagents minus the plant extract. An aliquot of $0.5 \mathrm{~mL}$ for each sample was mixed with $2.5 \mathrm{~mL}$ of a 10 -fold diluted Folin Ciocalteu reagent and $2 \mathrm{~mL}$ of $7.5 \%$ sodium carbonate in a test tube. The tubes were covered with parafilm and allowed to stand for $30 \mathrm{~min}$ at room temperature prior to taking the absorbance reading at $760 \mathrm{~nm}$ with the Glomax microtiter plate reader (Promega, U.S.A). Gallic acid was used as a standard at concentrations of 0.01 to $0.05 \mathrm{mg} / \mathrm{mL}(\mathrm{m} / \mathrm{v})$ in methanol. The total phenolics were expressed as gallic acid equivalent (GAE/mg of extracted material).

\section{Antibacterial activity of plant extracts Bacterial cultures}

The microbiota for the antimicrobial study included the surface water-borne isolate Klebsiella pneumoniae, commercial probiotics (combination of Lactobacillus acidophilus, Lactobacillus casei, Lactobacillus plantarum, Lactobacillus rhamnosus, Lactobacillus salivarius, Lactobacillus bifidum, Lactobacillus breve, Lactobacillus lactis, and Lactobacillus thermophillus), E. coli ATCC25922 $2^{\mathrm{m}}$, Salmonella typhimurium ATCC13311 ${ }^{\text {tm }}$, Shigella boydii ${\text { ATCC } 9207^{\mathrm{ma}}}$ and Vibrio parahaemolyticus ATCC17802 $2^{\mathrm{mx}}$. The microorganisms were maintained on Nutrient agar slant at $4{ }^{\circ} \mathrm{C}$ and sub-cultured on fresh Nutrient agar plates for $24 \mathrm{~h}$ at $37{ }^{\circ} \mathrm{C}$ prior to antimicrobial test. The Nutrient broth (NB) was used for the Minimum Inhibition Concentration (MIC) assay.

\section{Minimum inhibition concentration}

The microplate serial dilution method described by Eloff [31] was used to determine the Minimum Inhibition Concentration (MIC) values of the plant extracts against bacterial pathogens in 96 well microtiter plates. MIC was defined as the lowest concentration of the crude plant extract that inhibits bacterial growth after incubation period. The plant extract was serially diluted with distilled water to a concentration range of $2.5-0.02 \mathrm{mg} / \mathrm{mL}$ as described by Eloff [31]. Hundred microliters each of fresh bacterial cultures of probiotics mixture $\left(2.4 \times 10^{5} \mathrm{CFU} / \mathrm{mL}\right), S$. boydii $\left(2.4 \times 10^{5} \mathrm{CFU} / \mathrm{mL}\right)$ and S. typhimurium, E. coli, $V$. parahaemolyticus and $K$. pneumonia $\left(1.10 \times 10^{5} \mathrm{CFU} / \mathrm{mL}\right)$ were added to the wells of the microtiter plates. Similar serial dilutions were performed for Ampicillin $(1 \mathrm{mg} / \mathrm{mL})$ as a positive control and acetone as a negative control. Microtiter plates were covered and incubated at $37{ }^{\circ} \mathrm{C}$ for 
$24 \mathrm{~h}$. After incubation, $2 \mathrm{mg} / \mathrm{mL}$ of $p$-iodonitrotetrazolium violet (INT) reagent was used as an indicator of bacterial growth.

\section{Exposure of plant extracts to simulated gastric fluid}

Simulated gastric fluid (SGF) was prepared according to the US Pharmacopeia. Two grams of $\mathrm{NaCl}, 3.2 \mathrm{~g}$ pepsin (Sigma) and $80 \mathrm{~mL}$ of $1 \mathrm{M} \mathrm{HCl}$ were mixed together to make $1 \mathrm{~L}$ with distilled water. Five hundred microliters of each plant extract $(10 \mathrm{mg} / \mathrm{mL})$ that had an activity on MIC was incubated with $1 \mathrm{~mL}$ of SGF in a shaking incubator at $200 \mathrm{rpm}$ for $2 \mathrm{~h}$ at $37^{\circ} \mathrm{C}$. Following incubation, MIC was determined for residual antibacterial activities of the plant extracts.

\section{Synergistic activity}

The choice of leaf extracts for use in this assay was based on the lowest MIC values obtained in this study for the individual plant extracts. Following the investigation of the independent MIC of the selected plants, the synergistic or antagonistic interactions between the extracts were investigated. Aliquots of $100 \mu \mathrm{L}$ of bacterial cultures were grown in $100 \mathrm{~mL}$ of nutrient broth for $24 \mathrm{~h}$ at $37^{\circ} \mathrm{C}$. Different active plant extracts were combined at a ratio of 1:1 $(\mathrm{v} / \mathrm{v})$. The extract interactions were achieved by determining the MIC of the combinations exhibiting antibacterial activity to establish any interaction effect. The fractional inhibitory concentration (FIC) was calculated for the 1:1 combinations of the plants. This was determined with the equation below, where (i) and (ii) represented the different 1:1 plant combinations [37]. The FIC index was expressed as the sum of FIC (i) and FIC (ii) and this was used to classify the interaction as either synergistic $(\leq 0.50)$, additive $(0.50-1.00)$, indifferent $(>1.00-4.00)$ or antagonistic $(>4.00)$ [38].

$$
\begin{aligned}
& F I C(i) \frac{\text { MIC of }(a) \text { in combination with }(b)}{\text { MIC of }(a) \text { independently }} \\
& \text { FIC }(i i) \frac{\text { MIC of }(b) \text { in combination with }(a)}{\text { MIC of }(b) \text { independently }}
\end{aligned}
$$

\section{Evaluation of the cytotoxic activity of the plant extracts on cell culture}

The toxic effect of the extracts on muscle cell line $\mathrm{C} 2 \mathrm{C} 12$ was assessed by the 3-(4, 5-Dimethylthiazol-2-yl)-2,5-diphenyltetrazolium bromide (MTT) (Sigma $\left.{ }^{\circ}\right)$ method [39]. The amount of the insoluble formazan formed from reduction of MTT is directly proportional to the amount of viable cells. Cells were maintained in Dubleco's Modified Essential Medium (DMEM) supplemented with 10\% of Foetal bovine serum (FBS) and 1× Penicillin-Streptomycin-Neomycin (PSN). The $\mathrm{C} 2 \mathrm{C} 12$ cells were seeded at a density of $5 \times 10^{3}$ cells/well in a 96 well microtiter plates and incubated overnight at $37{ }^{\circ} \mathrm{C}$ in $5 \% \mathrm{CO}_{2}$. Cells were treated with various concentrations of the extracts with decreasing dilutions from 1000 to $200 \mu \mathrm{g} / \mathrm{mL}$ for $24 \mathrm{~h}$. After $24 \mathrm{~h}$ of incubation, the treatment medium was aspirated and $100 \mu \mathrm{L}$ of MTT at a concentration of $1 \mathrm{mg} / \mathrm{mL}$ was added and further incubated for $3 \mathrm{~h}$ at $37^{\circ} \mathrm{C}$ in the incubator. The formazan product was solubilised in $100 \mu \mathrm{L}$ of DMSO and was left for $30 \mathrm{~min}$. Spectrophotometric analysis was performed using the Glomax microtiter plate reader (Promega, U.S.A) at $560 \mathrm{~nm}$. Untreated cells with $1000 \mu \mathrm{g} / \mathrm{mL}$ of DMSO served as a negative control and Actinomycin $\mathrm{D}$ at a concentration of $40 \mu \mathrm{g} / \mathrm{mL}$ was used as a positive control. The percentage of cell viability was calculated using the $[(\mathrm{A} / \mathrm{B}) \times 100]$ formula, where $A$ is the absorbance value for treated cells and $B$ is the absorbance value for untreated cells.

\section{Results and discussion}

The plant extraction capabilities of the different solvents of varying polarities using the direct and serial exhaustive extraction approaches are indicated in Fig. 1. Extraction is a very important first step in the analysis of medicinal plant properties because the choice of solvent influences the types of compounds that can be extracted and ultimately, the biological activities imparted by the extracted compounds. Two extraction methods were used to check which one will give better yield. After drying the extracts, better yield was obtained when using the direct extraction method than the serial exhaustive method (results not shown). This is in agreement with the study conducted by Masoko et al. [40]. During the phytochemical analysis, more non-polar compounds were reactive to vanillin sulphuric acid reagent than the polar compounds (Fig. 2). This infers that both plant species contain more of non-polar than polar compounds based on the phytochemical profiles.

More compounds with antioxidant activity were observed in the intermediate and polar extractants in both plant species, i.e., ethyl acetate, acetone and methanol, which separated well in the polar and intermediate polar mobile systems (Fig. 3). This observation is not uncommon based on the study by Masoko and Eloff [41] and Sudha and Srinivasan [42] who reported the predominant presence of antioxidant compounds in polar than in non-polar plants extracts.

The total phenolic content (Fig. 4) of the leaf extracts of B. pilosa and D. cinerea was expressed using the gallic acid equivalent. Ethyl acetate, acetone and methanol extracts were selected for determination of the total phenolic content because of the high antioxidant activities of the extracts observed in this study (Fig. 3). Furthermore, phenolic compounds have been reported to exhibit antioxidants activity [43]. The total activity increased with an increase in polarity of the solvent for $D$. cinerea while and the converse was observed for B. pilosa. The type of 


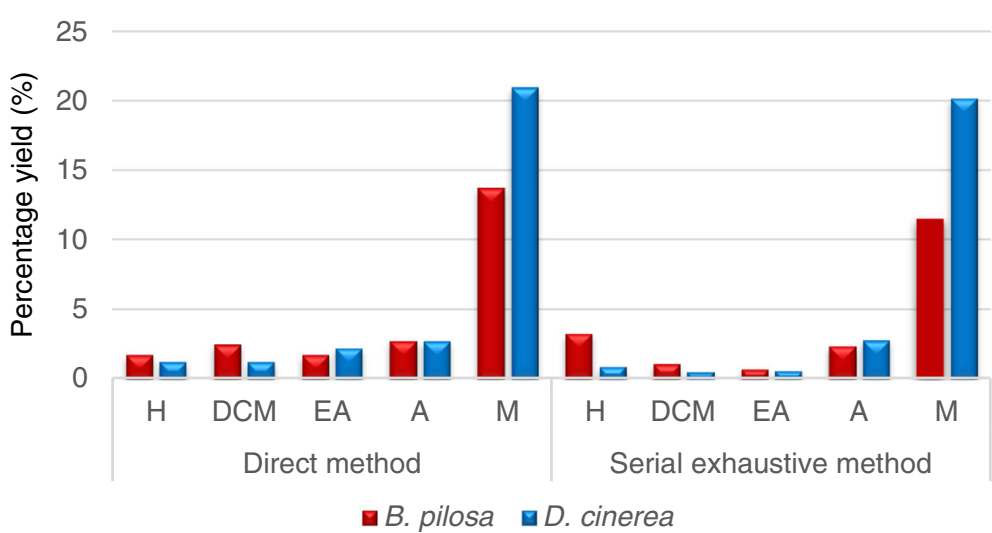

Fig. 1 The percentage yield of B. pilosa and D. cinerea leaf extracts following extraction using the direct and serial exhaustive extraction methods. $H$, hexane; DCM, dichloromethane; EA, ethyl acetate; $A$, acetone; $M$, methanol

solvent used for extraction plays a role in the ability to extract phenolic components from plant materials [44]. Several studies have shown that methanol and acetone can extract higher amount of phenolics [45-47] and the presence of phenolic compounds might be responsible for the bioactivity of these extracts. The positive association between total phenolic content and antioxidant activity of B. pilosa and D. cinerea was observed, because the distribution of antioxidant compounds from $D$. cinerea was dominant in the polar to intermediate polar mobile system and the phenolic activity was higher in the polar extracts. On the contrary, the antioxidant activity for $B$. pilosa was apparent in the intermediate to non-polar mobile systems while the total phenolic activity was higher in the intermediate polar extract (Figs. 3 and 4).

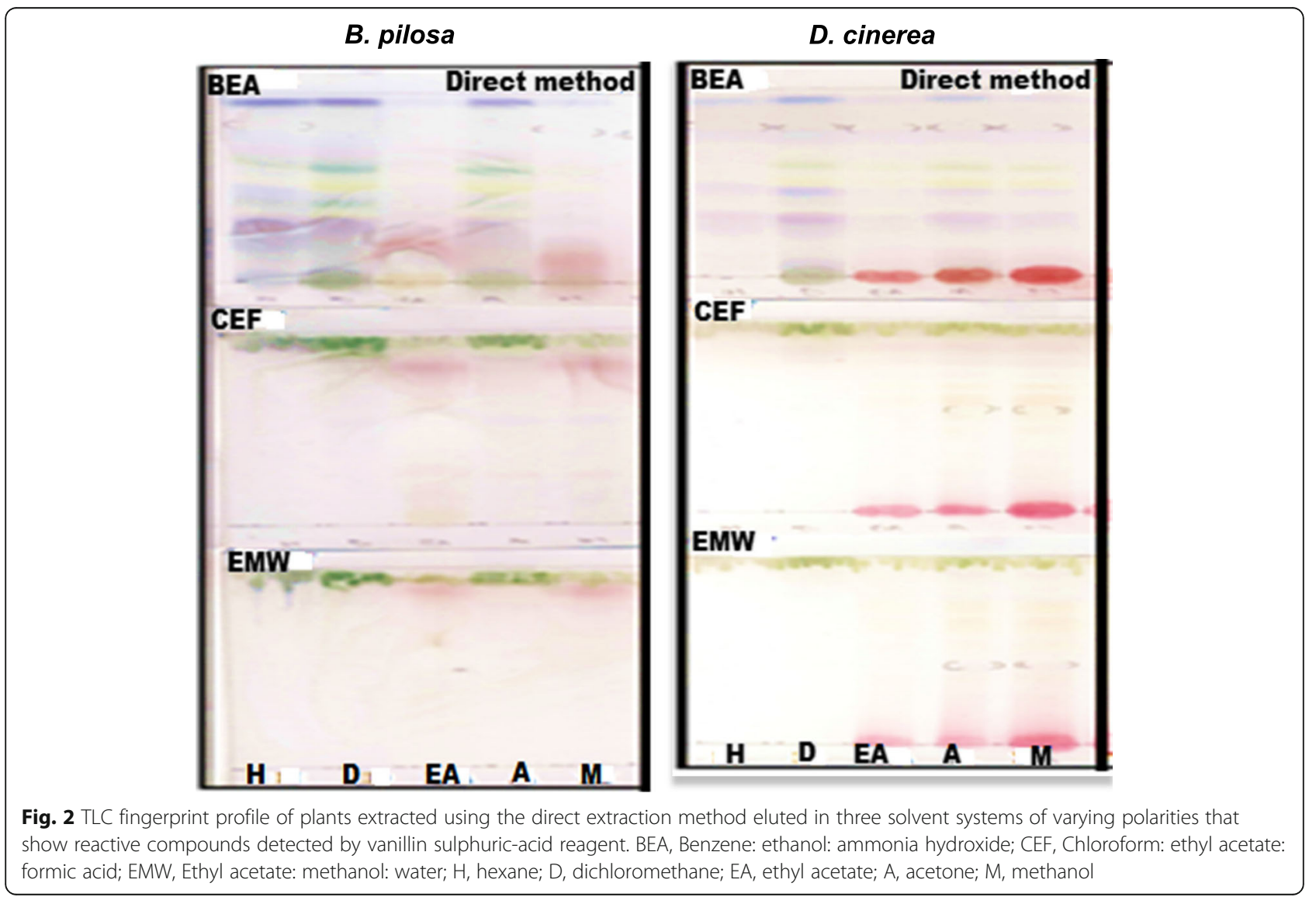


B. pilosa

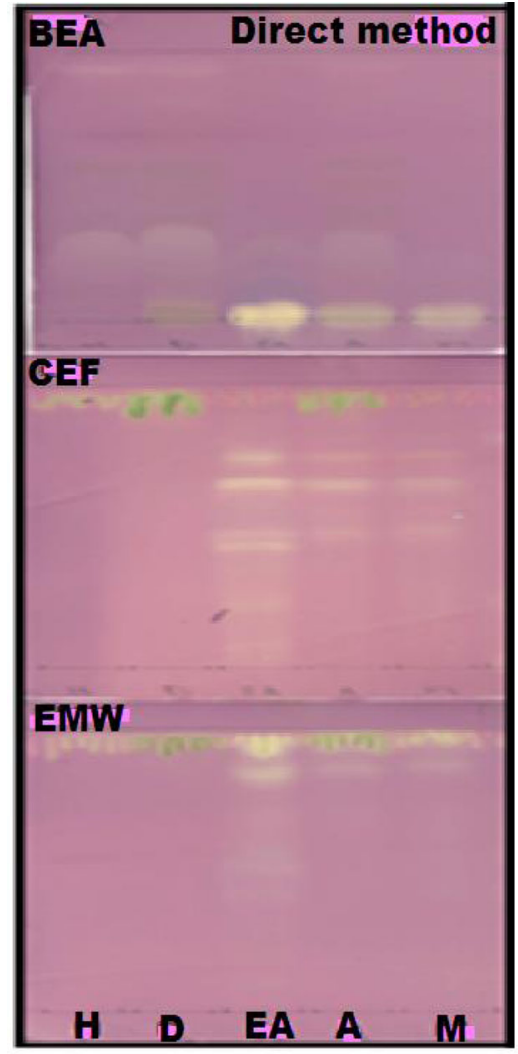

D. cinerea

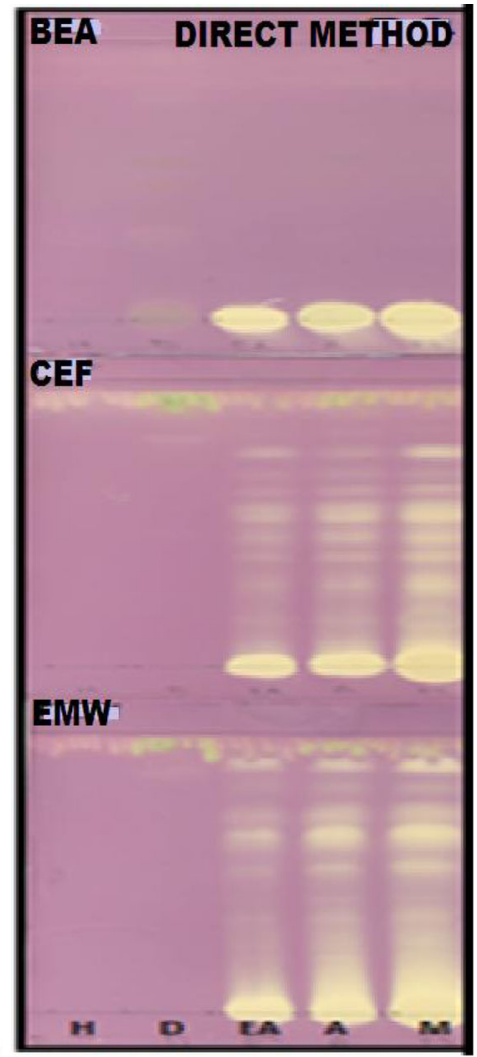

Fig. 3 The presence of antioxidant activity depicted by the yellow bands against a purple background. DPPH (0.2\%) in methanol was used as an indicator. BEA, Benzene: ethanol: ammonia hydroxide; CEF, Chloroform: ethyl acetate: formic acid; EMW, Ethyl acetate: methanol: water; $H$, hexane; $D$, dichloromethane; EA, ethyl acetate; A, acetone; M, methanol

The phytochemical compounds assayed in B. pilosa showed a predominance of steroids whereas in $D$. cinerea the phenols saponins were the most dominant (Table 1).

The antibacterial activity of the medicinal plant extracts varied according to the bacteria tested and the type of solvent used for the extraction. The dichloromethane extracts of both plant species had high antibacterial activity against all the bacterial species tested with an average MIC value of $0.56 \mathrm{mg} / \mathrm{mL}$ (Table 2). Nevertheless, K. pneumoniae was sensitive to B. pilosa

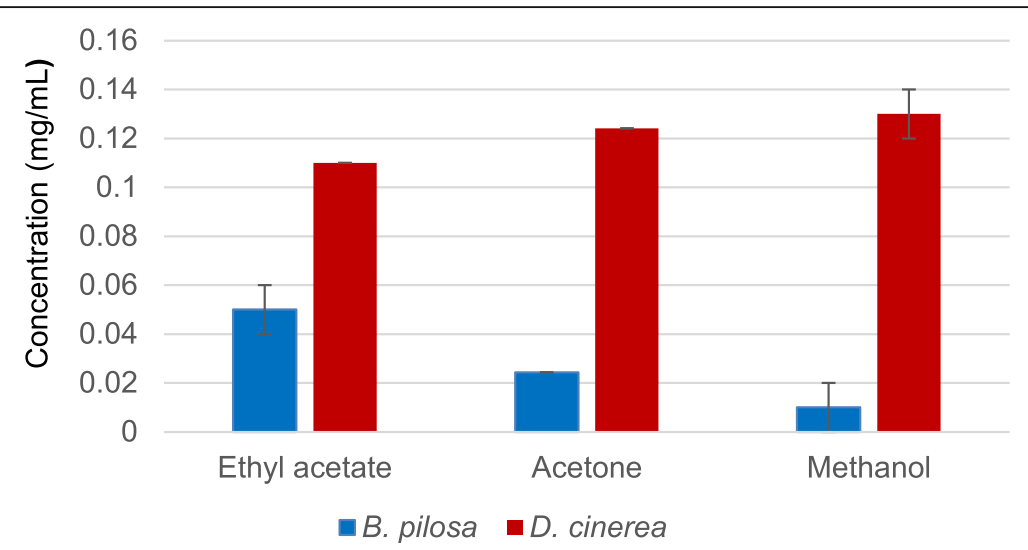

Fig. 4 The total phenolic content of leaf extracts of B. pilosa and D. cinerea extracted by ethyl acetate, acetone and methanol using the direct extraction method 
Table 1 Phytoconstituents of B. pilosa and D. cinerea leaf extracts

\begin{tabular}{lll}
\hline Phytochemicals tested & B. pilosa & D. cinerea \\
\hline Phenols & - & +++ \\
Steroids & +++ & + \\
Flavonoids & + & ++ \\
Saponins & - & +++ \\
Terpenoids & ++ & + \\
\hline
\end{tabular}

- Absent, + slightly present, ++ moderately present, +++ highly present

and $D$. cinerea extracts but resistant to hexane extracts of both plant species. Ethyl acetate extract of $D$. cinerea showed no activity against most of the tested bacteria, including the probiotics. The dichloromethane extract of both plant species specifically showed higher antibacterial activities against the test organisms, with the most being against the probiotics for $B$. pilosa. The lower antibacterial activities are generally biased towards the non-polar solvents for B. pilosa, and this is congruent with the dominance of anti-oxidant activities and phenolic content which separated more in the non-polar solvents as well. It is noteworthy to mention that all the extracts were less potent against the test bacteria due to the observed high MIC values and again the potency of ampicillin which was used as a positive control. Hence, these extracts may not have good candidates as drug leads for antibacterial activity because of these high MIC values due to the importance of the potency of the antibacterial agent in drug development, amongst other factors. Comparatively, the dichloromethane extracts of both plant species gave lower MIC values against all the test organisms and the probiotics,

Table 2 The MIC values of B. pilosa and D. cinerea leaf extracts against selected microorganisms

\begin{tabular}{|c|c|c|c|c|c|c|c|}
\hline \multirow[t]{2}{*}{ Bacteria } & \multirow[t]{2}{*}{ Plants } & \multicolumn{6}{|c|}{ MIC values (mg/mL) } \\
\hline & & $\mathrm{H}$ & $\mathrm{D}$ & EA & A & M & Ampicillin \\
\hline \multirow[t]{2}{*}{ S. typhimurium } & B. pilosa & 1.25 & 1.88 & 0.31 & 2.5 & 2.5 & 0.23 \\
\hline & D. cinerea & 2.5 & 1.25 & 2.5 & 1.25 & 1.25 & \\
\hline \multirow[t]{2}{*}{ S. boydii } & B. pilosa & 0.16 & 0.08 & 0.94 & 0.16 & 0.16 & 0.04 \\
\hline & D. cinerea & 1.25 & 0.04 & 0.31 & 0.31 & 0.16 & \\
\hline \multirow[t]{2}{*}{ V. parahaemolyticus } & B. pilosa & 0.31 & 0.31 & 0.47 & 0.47 & 0.94 & 0.12 \\
\hline & D. cinerea & 0.63 & 1.88 & 2.5 & 1.88 & 2.5 & \\
\hline \multirow[t]{2}{*}{ E. coli } & B. pilosa & 1.25 & 0.08 & 0.63 & 0.63 & 1.25 & 0.31 \\
\hline & D. cinerea & 2.5 & 0.63 & 2.5 & 2.5 & 2.5 & \\
\hline \multirow[t]{2}{*}{ K. pneumoniae } & B. pilosa & 2.5 & 0.12 & 0.31 & 0.31 & 0.31 & 0.47 \\
\hline & D. cinerea & 2.5 & 0.31 & 0.63 & 0.16 & 0.16 & \\
\hline \multirow[t]{2}{*}{ Probiotics } & B. pilosa & 0.31 & 0.01 & 0.31 & 0.16 & 0.16 & 0.47 \\
\hline & D. cinerea & 2.5 & 0.16 & 2.5 & 1.25 & 1.25 & \\
\hline Average & & 1.47 & 0.56 & 1.16 & 0.97 & 1.1 & \\
\hline
\end{tabular}

$H$ hexane, $D$ dichloromethane, $E A$ ethyl acetate, $A$ acetone, $M$ methanol although no antioxidant activity was detected for this solvent in this study. Shigella sp. was the most susceptible of all the test bacteria with an MIC values of $0.04 \mathrm{mg} / \mathrm{mL}$. The observed antibacterial activity against the probiotics must be considered by the consumers and traditional healers for continuous consumption of the traditional remedies as this may pose a significant health risk in sick patients and can further weaken their immune system. Destabilisation of probiotic activity in the human gut often creates an imbalance of gut flora and this aggravates diarrhoeal episodes. The imbalance of the intestinal flora may consequently lead to the surge of opportunistic pathogens, and this occurrence may inadvertently reverse the beneficial effect of the plant extract, and eventually produce a detrimental effect. Some of the extracts had high MIC values $(1.25-2.5 \mathrm{mg} / \mathrm{mL})$ that is an indication of lack of activity against tested microorganisms. The secondary metabolites, namely, terpenoids, steroids and flavonoids were detected in the extracts (Table 1) and these compounds are known to have antibacterial activities [48]. Previous studies has reported antibacterial activity of D. cinerea against Staphylococcus aureus, Bacillus subtilis, Escherichia coli, Pseudomonas aeruginosa and Candida albicans [49]. da Silva et al. [50] also reported antibacterial activity of $B$. pilosa against Staphylococcus aureus. The findings in this study that polar solvents such as acetone and methanol produced better antioxidant and antibacterial activities, support the traditional use of water as an extractant for preparations of remedies.

All the plant extracts that had MIC value $\leq 1 \mathrm{mg} / \mathrm{mL}$ against tested bacteria were exposed to the simulated gastric fluid (SGF). Table 3 shows the results of the plant extracts after exposure to the SGF. B. pilosa and D. cinerea hexane extracts lost their antibacterial activity following the

Table 3 The MIC values of B. pilosa and D. cinerea leaf extracts after exposure to simulated gastric fluid

\begin{tabular}{llllllll}
\hline Bacteria & Plants & \multicolumn{7}{c}{ MIC values $(\mathrm{mg} / \mathrm{mL})$} & & \\
\cline { 3 - 8 } & & H & D & EA & A & M & Ampicillin \\
\hline S. typhimurium & B. pilosa & 2.5 & NA & 2.5 & NT & NT & 0.63 \\
& D. cinerea & NA & NA & NT & 1.25 & 1.25 & \\
S. boydii & B. pilosa & NA & 1.25 & 2.5 & 1.25 & 1.25 & 0.31 \\
& D. cinerea & NA & 0.63 & 1.25 & 0.63 & 1.25 & \\
V. parahaemolyticus & B. pilosa & NA & NA & 1.25 & 1.25 & 1.25 & 0.31 \\
& D. cinerea & NA & NA & NA & 2.5 & NA & \\
E. coli & B. pilosa & NA & 1.25 & 1.25 & 2.5 & NA & 0.63 \\
K. pneumoniae & D. cinerea & NT & NA & NT & NT & NA & \\
& B. pilosa & NT & 1.25 & 2.5 & 2.5 & NA & 0.63 \\
\hline
\end{tabular}

$N T$ Not tested, NA No activity, $H$ hexane, $D$ dichloromethane, $E A$ ethyl acetate, $A$ acetone, $M$ methanol 
Table 4 MIC values of synergistic activity for B. pilosa and D. cinerea leaf extracts

\begin{tabular}{llll}
\hline Bacteria & $\begin{array}{l}\text { B. pilosa }+ \text { D. cinerea } \\
\text { (independent MIC, } \\
\mathrm{mg} / \mathrm{mL} \text { ) }\end{array}$ & $\begin{array}{l}\mathrm{MIC} \text { values in } \\
\mathrm{mg} / \mathrm{mL} \\
\text { (combination) }\end{array}$ & $\mathrm{FIC} \mathrm{index}$ \\
\hline S. typhimurium & $\mathrm{EA}(0.31)+\mathrm{D}(1.25)$ & 0.63 & 2.53 \\
S. boydii & $\mathrm{D}(0.08)+\mathrm{D}(0.04)$ & 0.08 & 3 \\
V. parahaemolyticus & $\mathrm{H}(0.31)+\mathrm{H}(0.63)$ & 0.08 & 0.38 \\
E. coli & $\mathrm{D}(0.08)+\mathrm{D}(0.63)$ & 0.16 & 2.25 \\
K. pneumoniae & $\mathrm{D}(0.12)+\mathrm{D}(0.31)$ & 0.31 & 3.58 \\
\hline
\end{tabular}

$E A$ ethyl acetate, $D$ dichloromethane, $H$ hexane

treatment of SGF. Vermaak et al. [51] and Keating et al. [52] reported that SGF can modify or degrade antibacterial compounds in plants extracts and this can subsequently lead to the loss of initial antibacterial activity in the extracts. In the present study, loss of activity was observed with polar extracts of $D$. cinerea against $S$. typhimurium as compared with the plant extracts alone (Table 3). Interestingly, the gastric fluid played a protective role towards the bacteria by reducing their sensitivity to the extracts. The same effect was observed with ampicillin, which served as the positive control. This protective phenomenon could explain their tenacious survival in the human gut during infections. The results obtained suggest that most of the activities of the orally consumed plant extracts are weakened because of the interaction with the SGF.

All extracts with the lowest MIC values for all the bacteria used were further subjected to synergistic analysis. Table 4 shows the results of the MIC values of synergistic activity of B. pilosa and D. cinerea leaf extracts. Synergy was observed with an FID index of 0.38 for the combination of extracts of B. pilosa and D. cinerea against $V$. parahaemolyticus, whereas the antibacterial activity of the other combinations did not improve from the independent MIC values of the individual B. pilosa and $D$. cinerea extracts.
Cytotoxicity effect of the extracts of $D$. cinerea and B. pilosa leaves were investigated against $\mathrm{C} 2 \mathrm{C} 12$ cell line and the results are shown in Fig. 5. The effects of extracts were compared with the positive control after exposure for 24 and $48 \mathrm{~h}$. None of the crude extracts at different concentrations were toxic to C2C12 cell lines for both plants. Cytotoxicity of these two plants has been investigated for different cell line by other authors and the results showed no effect on the cell line after the treatment $[53,54]$. The fact that there was no toxicity observed on the cell line makes the plants extracts beneficial to the rural community of South Africa. This is good especially in the case of B. pilosa which is used as a vegetable as part of everyday food by the African people living in the rural villages.

\section{Conclusion}

Waterborne bacterial infections are a serious problem in many developing countries and the decline in fresh water resources aggravates these incidences. Africans preferentially use traditional medicine either as a choice or due to financial constraints wherein western medicine is not an option. While the biological activities of plant extracts can be empirically validated, as was the case in this study, it remains important to investigate other unintended effects that may result in secondary complications from consumption of these medicinal preparations. This current study has shown that leaf extracts of $B$. pilos $a$ and $D$. cinerea are potential sources of antioxidant and antimicrobial agents, which can find application in the treatment of bacterial diarrhoea conditions. Polar solvents such as acetone and methanol showed good antioxidant and antibacterial activities, and this is an advantage to herbalist and traditional healers who use water for preparations of remedies. However, the loss of some antibacterial activity when plant extracts were exposed to gastric fluid is concerning because this may lead to continuous survival of the pathogens in the

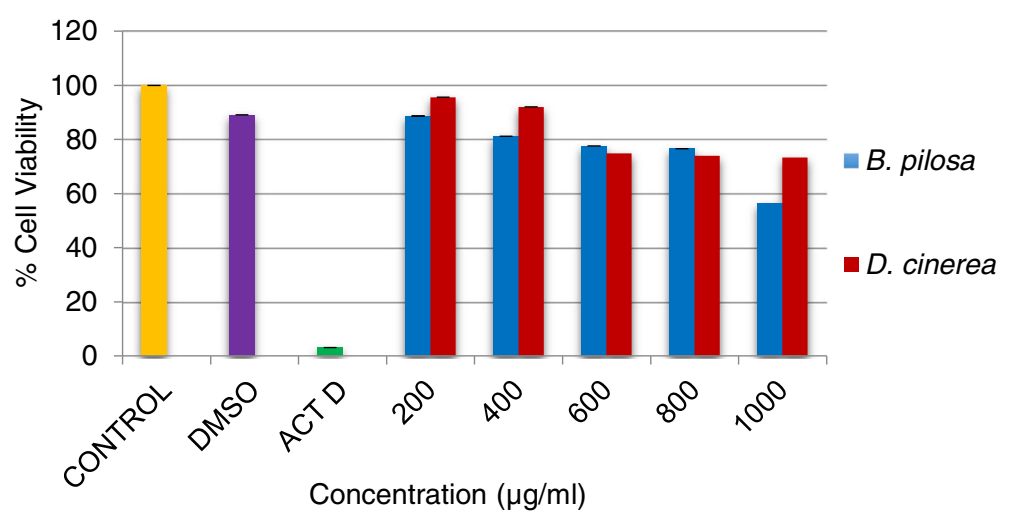

Fig. 5 The cytotoxic effects of B. pilosa and D. cinerea extracts against C2C12 
human gut and prolonged disease episodes. In addition, the adverse effect of plant extracts on the probiotics can be circumvented by re-dosing with probiotics food products such as fermented porridge or other fermented food products which are naturally produced and consumed in many rural African communities.

\section{Abbreviations}

BEA: Benzene: ethanol: ammonia hydroxide; CEF: Chloroform: ethyl acetate: formic acid; DMEM: Dubleco's Modified Essential Medium; EMW: Ethyl acetate: methanol: water; FBS: Foetal bovine serum; INT: $p$-iodonitrotetrazolium violet; MTT: (4,5-Dimethylthiazol-2-yl)-2,5-diphenyltetrazolium bromide; PSN: PenicillinStreptomycin-Neomycin; SGF: Simulated gastric fluid; TLC: Thin layer chromatography

\section{Acknowledgements}

The authors are thankful to Mr. A Njanje for assistance with tissue culture assays and the University Herbarium for helping with the identification of the plants species

\section{Funding}

We would like to thank National Research Foundation for student financial support under Scarce Skills Doctoral study programme, grant number 101384.

\section{Availability of data and materials}

All data generated and analysed during this study are included in this article.

\section{Authors' contributions}

PDS carried out the experiments, analysed and interpreted the data on efficacy of plant materials, influence of gastric juice and synergistic effects of combinatorial treatments of bacteria. KMM, SCT contributed to the conception, the design of the study, the interpretation of the data. PM, analysed and interpreted the data. All authors prepared, proofread and approved the final manuscript.

\section{Authors' information}

Ms. Pfarelo Daphney Shandukani, Doctoral Student; Dr. Shonisani Cathphonia Tshidino and Dr. Kgabo Maureen Moganedi, Senior Lecturers in Biochemistry and Microbiology respectively, and Prof Peter Masoko, Professor in Microbiology, Department of Biochemistry, Microbiology and Biotechnology, Faculty of Science and Agriculture, University of Limpopo (South Africa).

\section{Ethics approval and consent to participate}

Not applicable.

\section{Competing interests}

The authors declare that they have no competing interests.

\section{Publisher's Note}

Springer Nature remains neutral with regard to jurisdictional claims in published maps and institutional affiliations.

Received: 8 August 2017 Accepted: 8 May 2018

Published online: 01 June 2018

\section{References}

1. State of Rivers Report. Mthatha river systems, no .14. 2008. http://www.dwa. gov.za/IWQS/rhp/state_of_rivers/ecape_04/State_of_Rivers_Report_No_14_ Mthatha_River_System_2008.pdf. (2017-08-04).

2. Nova Scotia Environment. Using a surface water source for drinking. 2011. https:/novascotia.ca/nse/surface.water/docs/SurfaceWaterQA.pdf. (2017-08-04).

3. European Centre for Disease Prevention and Control (ECDC). Antibiotic resistance major public health problem. 2012. http://www. medicalnewstoday.com/articles/252956.php (2017-08-04)

4. Statistics South Africa. Levels and trends of morbidity and mortality among children aged under-five years in South Africa, 2006-2010. Pretoria; 2012. http://www.statssa.gov.za/publications/Report-03-09-10/Report-03-09102010.pdf (2017-08-04)
5. Johnson J, Kuskowski M, Menard M, Gajewski A, Xercavins M, Garau J. Similarity between human and chicken Escherichia coli isolates in relation to ciprofloxacin resistance status. J Infect Dis. 2006;194(1):71-8.

6. Debruyne D. Clinical pharmacokinetics of fluconazole in superficial and systemic mycoses. Clin Pharmacol. 1997;33:52-7.

7. Shai LJ, McGaw LJ, Aderogba MA, Mdee LK, Eloff JN. Triterpenoids with antifungal and antibacterial activity from Curtisia dentata (Burm.F) C.A. Sm. Leaves. J Ethnopharmacol. 2008;119:238-24.

8. Sofowora A. Medicinal plants and traditional medicine in Africa. Ibadan: Spectrum Books Ltd; 1993. p. 19-289.

9. Matsheta MS, Mulaudzi FM. The perception of traditional healers of cervical cancer care at Ga Mothapo village in Limpopo Province. IAJIKS. 2008;7:103-16.

10. Mabogo DEN. The ethnobotany of the vhaVenda. Master of science dissertation. South Africa: University of Pretoria; 1990.

11. Tchiegang C, Mbougueng PD. Chemical composition of spices used in the cooking of nah poh and nkui of western Cameroon. Tropicultura. 2005;23:193-200.

12. Kuate D, Etoundi BCO, Ngondi JL, Oben JE. Effects of Dichrostachys glomerata spice on cardiovascular diseases risk factors in normoglycemic and type 2 diabetic obese volunteers. Food Res Int. 2011:44(5):1197-202.

13. World Agroforestry Centre. Agroforestree Database. Nairobi: World Agroforestry Centre; 2005. http://www.worldagroforestry.org/output/ agroforestree-database. (2017-08-04)

14. Abdou Bouba A, Njintang YN, Scher J, Mbofung CMF. Phenolic compounds and radical scavenging potential of twenty Cameroonian spices. Agric Biol J North America. 2010;1:213-24.

15. Kuate D. Effects of some spices on glucose and lipid metabolism and oxidative stress. Cameroon: PhD Thesis. University of Yaounde.

16. Kuate D, Etoundi BCO, Soukontoua YB, Ngondi JL, Oben JE. Antioxidant characteristics of Dichrostachys glomerata spice extracts. CyTA J Food. 2010;8:23-37.

17. Fankam AG, Kuete V, Voukeng IK, Kuiate JR, Pages JM. Antibacterial activities of selected Cameroonian spices and their synergistic effects with antibiotics against multidrug-resistant phenotypes. BMC Compl Altern Med. 2011;11:104-14.

18. Fotie J, Nkengfack AE, Peter MG, Heydenreich M, Fomum ZT. Chemical constituents of the ethyl acetate extracts of the stem bark and fruits of Dichrostachys cinerea and the roots of Parkia bicolor. Bull Chem Soc Ethiop. 2004;18(1):111-5.

19. Department of Agriculture, Forestry \& Fisheries (DAFF). Most common Indigenous food crops of South Africa; 2013. p. 9.

20. Botanical Society of Britain and Ireland. Archived from the original (x|s) on 2015-01-25. https://en.wikipedia.org/wiki/Bidens_pilosa. (2017-08-04).

21. Pozharitskaya ON, Shikov AN, Makarova MN, Kosman VM, Faustova NM, Tesakova SV, Makarov VG, Galambosi B. Anti-inflammatory activity of a HPLC-fingerprinted aqueous infusion of aerial part of Bidens tripartita $L$. Phytomedicine. 2010;17(60):463-8.

22. Grubben GJH, Denton OA. Plant resources of tropical Africa 2. NJB. 2004;23(3):298

23. Redl K, Breu W, Davis B, Bauer R. Anti-inflammatory active polyacetylenes from Bidens campylotheca. Planta Med. 1994;60(1):58-62.

24. Chiang LC, Cheng HY, Liu MC, Chiang W, Lin CC. In vitro anti-herpes simplex viruses and anti-adenoviruses activity of twelve traditionally used medicinal plants in Taiwan. Biol Pharm Bull. 2003;26:1600-4.

25. Deba F, Xuan TD, Yasuda M, Tawata S. Chemical composition and antioxidant, antibacterial and antifungal activities of the essential oils from Bidens pilosa Linn. var. radiata. Food Control. 2008;19:346-52.

26. Tamokou JD, Tala FM, Wabo KH, Kuiate JR, Tane P. Antimicrobial activities of methanol extract and compounds from stem bark of Vismia rubescens. Ethnopharmacol. 2009;124:571-5.

27. Rojas JJ, Ochoa VJ, Ocampo SA, Muñoz JF. Screening for antimicrobial activity of ten medicinal plants used in Colombian folkloric medicine: a possible alternative in the treatment of non-nosocomial infections. BMC Complement Altern Med. 2006;6:2.

28. Samie A, Obi CL, Bessong PO, Namrita L. Activity profiles of fourteen selected medicinal plants from rural Venda communities in South Africa against fifteen clinical bacteria species. Afr J Biotechnol. 2005:4:1443-145.

29. Okpara JO. Evaluation of ethanolic extracts of Dichrostachys glomerata and Psidium guajava leaves for antidiarrhoeal activity. Doctor of philosophy dissertation. Zaria: Ahmadu Bello University; 2008.

30. Kotze M, Eloff JN. Extraction of antibacterial compounds from Combretum microphyllum (Combretaceae). S Afr J Bot. 2002;68:62-7.

31. Eloff JNA. Sensitive and quick microplate method to determine the minimal inhibitory concentration of plant extracts for bacteria. Planta Med. 1998;64:711-3. 
32. Trease GE, Evans WC. Text of Pharmacognosy, vol. 14. London: Walter Burns Sanders publishing; 1989. p. 542-5.

33. Borokini Tl, Omotayo TO. Phytochemical and ethnobotanical study of some selected medicinal plants from Nigeria. JMPR. 2012;6:1106-18.

34. Odebiyi OO, Sofowara EA. Phytochemical screening of Nigerian medicinal plants. Llodydia. 1978:41:234-46.

35. Deby C, Margotteaux G. Relationship between essential fatty acids and tissue antioxidant levels in mice. C R Soc Biol Fil. 1970;165:2675-81.

36. Savitree M, Isara P, Nittaya SL, Worapan S. Radical scavenging activity and total phenolic content of medicinal plants used in primary health care. J Pharm Sci. 2004;9(1):32-5

37. Mabona U, Viljoen A, Shikanga E, Marston A, Van Vuuren S. Antimicrobial activity of southern African medicinal plants with dermatological relevance: from an ethnopharmacological screening approach, to combination studies and the isolation of a bioactive compound. J Ethnopharmacol. 2013;148(1):45-55.

38. Van Vuuren SF, Viljoen AM. In vitro evidence of phyto-synergy for plant part combinations of Croton gratissimus (Euphorbiaceae) used in African traditional healing. J Ethnopharmacol. 2008;119(3):700-4.

39. Mosaddegh M, Esmaeili S, Naghibi F, Moghadam MH, Haeri A, Pirani A, Moazzeni H. Ethnomedical survey and cytotoxic activity of medicinal plants extracts used in Kohgiluyeh and Boyerahmad provinces in Iran. J Herbs Spices Med Plants. 2012;18:211-21.

40. Masoko P, Mokgotho MP, Mbazima VG, Mampuru L. Biological activities of Typha capensis (Typhaceae) from Limpopo Province (South Africa). Afr J Biotechnol. 2008;7(20):3743-8.

41. Masoko P, Eloff JN. Screening of 24 south African Combretum and 6 Terminalia (Combretaceae) species for antioxidant activities. AJTCAM. 2007:4:231-9.

42. Sudha A, Srinivasan P. Bioassay-guided isolation and antioxidant evaluation of flavonoid compound from aerial parts of Lippia nodiflora L. Biomed Res Int. 2014;2014:Article ID 549836. http://dx.doi.org/10.1155/2014/549836.

43. Soobrattee MA, Neergheen VS, Luximon-Ramma A, Aruoma OI, Bahorun OT. Phenolics as potential antioxidant therapeutic agents: mechanism and actions. Mutat Res. 2005;579:200-13.

44. Verma PK, Sultana M, Dar MA, Prawez S, Raina R. Quantitative analysis of total phenolic, flavonoids and tannin contents in acetone and n-hexane extracts of Ageratum conyzoides. Int J Chem Tech Res. 2012;4(3):996-9.

45. Boeing JS, Barizão ÉO, Silva BC, Montanher PF, Almeida VC, Visentainer JV. Evaluation of solvent effect on the extraction of phenolic compounds and antioxidant capacities from the berries: application of principal component analysis. Chem Cent J. 2014:8:48.

46. Addai ZR, Abdullah A, Mutalib S. Effect of extraction solvents on the phenolic content and antioxidant properties of two papaya cultivars. J Med Plants Res. 2013;7(47):3354-9.

47. Tomsone L, Kruma Z, Galoburda R. Comparison of different solvents and extraction methods for isolation of phenolic compounds from horseradish roots (Armoracia rusticana). Int J Biol Biomol Agricult Food Biotechnol Eng. 2012;6(4):236-41.

48. Compean KL, Ynalvez RA. Antimicrobial activity of plant secondary metabolites: a review. Res J Med Plants. 2014:8:204-13.

49. Omukhulu NJ, Mweu MC, Kariuki NP, Wangari MC. Phytochemical characterization, antibacterial screening and toxicity evaluation of Dichrostachys cinerea. Int J Med Plant Res. 2012;1:32-7.

50. da Silva JJ, Cerdeira CD, Chavasco JM, Cintra ABP, da Silva CBP, de Mendonca AN, Tati Ishikawa T, Boriollo MFG, Chavasco JK. In vitro screening for antibacterial activity of Bidens pilosa Linne' and Annona crassiflora Mart. Against oxacillin resistant Staphylococcus aureus (ORSA) from the aerial environment at the dental clinic. Rev Inst Med Trop. 2014;56(4):333-40.

51. Vermaak I, Viljoen AM, Hamman JH, van Vuuren SF. The effect of simulated gastrointestinal conditions on the antimicrobial activity and chemical composition of indigenous south African plant extracts. S Afr J Bot. 2009;75(3):594-9.

52. Keating L, Hayes J, Moane S, Lehane M, O'Doherty S, Kingston R, Furey A. The effect of simulated gastro-intestinal conditions on the antioxidant activity of herbal preparations made from native Irish hawthorn. J Herb Med. 2014:4:127-33

53. Chavasco JM, Feliphe BHMPE, Cerdeira CD, Leandro FD, LFL C, da Silva I Jr, Chavasco JK, ALT D. Evaluation of antimicrobial and cytotoxic activities of plant extracts from southern Minas Gerais Cerrado. Rev Inst Med. 2014;56(1). https://doi.org/10.1590/S0036-46652014000100002.

54. Mwangi GG, Wagacha JM, Nguta JM, Mbaria JM. Brine shrimp cytotoxicity and antimalarial activity of plants traditionally used in treatment of malaria in Msambweni district. Pharm Bio. 2015;53(4):588-93.

\section{Ready to submit your research? Choose BMC and benefit from:}

- fast, convenient online submission

- thorough peer review by experienced researchers in your field

- rapid publication on acceptance

- support for research data, including large and complex data types

- gold Open Access which fosters wider collaboration and increased citations

- maximum visibility for your research: over $100 \mathrm{M}$ website views per year

At BMC, research is always in progress.

Learn more biomedcentral.com/submissions 